\title{
MANA-MÚSICA: INTERPRETAÇÕES DE MÚSICAS, CULTOS E DISCURSOS EVANGÉLICOS
}

\author{
Euridiana Silva Souza ${ }^{1}$
}

\section{A Palavra cantada: localizando tema e teoria}

De acordo com as reflexões de Foucault, não pretendo que este trabalho se limite apoiado em uma única disciplina, uma vez que estas não comportam tudo em si mesmas. Atualmente, com os muitos discursos de multi, inter, trans ou mesmo indisciplinaridades, podemos perceber o quanto os limites das disciplinas, que se pretendiam presas em gabinetes, departamentos, sessões de bibliotecas ou estantes de livrarias, são tênues. Ainda que eu me veja como uma educadora musical e etnomusicóloga, este é um trabalho, me utilizando das idéias de Mary Douglas em Pureza e Perigo (1966), situado na margem, na intercessão, na semi-identidade, na impureza. Não é puramente antropológico, sociológico ou musicológico. Na indecisão de escolher uma única área de conhecimento, resolvi passar por alguns recortes e visões teóricas sobre música, religião e discurso no ambiente das igrejas evangélicas na capital de Minas Gerais - Belo Horizonte.

Por ser o chamado "mundo evangélico" muito amplo, restringi-me às igrejas batistas por estar mais familiarizada com elas, devido à minha história de vida. Sob o nome Batista encontram-se igrejas muito diferentes, ligadas por uma doutrina comum, mas com práticas cotidianas muitas vezes opostas. Para o estudo, duas igrejas foram selecionadas por serem díspares, tanto em seus perfis de membros, quanto em suas práticas e tamanhos, mas também, por serem referências em suas práticas musicais, salvo todas as proporções que isso alcança. Uma delas, de orientação pentecostal ${ }^{2}$, igreja grande e engajada no mundo contemporâneo, aberta às mudanças, aos estilos, à mídia e ao marketing, mesclando emoção, espetáculo e impacto social em busca de seu crescimento. A outra, pequena, racional e profundamente comprometida com sua tradição doutrinária e musical, buscando manter-se e crescer na medida em que se afasta de tudo que o mundo ${ }^{3}$ proporciona - com especial ênfase aos diversos estilos musicais populares. Ambas, contudo, batistas.

\footnotetext{
${ }^{1}$ Serviço Social da Industria - Federação de Indústrias do Estado de Minas Gerais, Brasil.

${ }^{2} \mathrm{O}$ nome vem de Pentecostes, festa religiosa dos judeus, dia em que o Espírito Santo desceu sobre os apóstolos [...] Por isso o centro do pentecostalismo é o batismo no Espírito Santo, que não é um rito como o batismo com água, e, sim uma presença toda especial do Espírito Santo, que tem como sinal exterior proferir algumas palavras estranhas [glossolalia] (Santos; 2002:15)

${ }_{3}^{3}$ Mundo é um termo corrente na linguagem evangélica, usado "para se referir ao espaço que não é o da igreja, dos salvos, daqueles que estão resguardados do mal e do pecado (...)" (Cunha; 2004:190). No
} 
É possível observar, seja através da veiculação da mídia, ou mesmo entre conhecidos que sejam evangélicos, que a música circula livremente entre diferentes igrejas, como afirma Zilmar Rodrigues de Souza: "O mercado musical evangélico possuirá a partir de então [1990], caráter monopolista e ecumênico, pois, mesmo as igrejas evangélicas possuindo pontos doutrinários divergentes, a música evangélica será, logo, um fator de unidade entre elas" (2003). No entanto, mais que unir, muitas vezes as práticas musicais do dito "momento de louvor e adoração" como veremos aqui, distanciam igrejas próximas nominalmente. As muitas músicas de igrejas evangélicas vinculadas à mídia, e veiculadas por ela, transitam sim entre diferentes denominações ${ }^{4}$, mas não evidenciam sempre um fator de unidade. $\mathrm{O}$ fato de uma música chegar à outra denominação pode ser visto como uma forma de aceitação positiva, para a qual se aplicaria a fala do autor; mas, também se pode ter uma aceitação negativa, que acarretaria uma postura de separação, crítica e mesmo de se evitar determinada música (Souza, 2006), uma vez que a "música representa a cultura de duas formas, como forma de expressão comum para a humanidade, e como uma das mais extremas manifestações de diferença" (Bohlman, 2003:47) ${ }^{5}$.

Não tratando aqui de juízo de valores e operando no sistema das verdades parciais de cada comunidade estudada, e em última instância, nas verdades individuais das pessoas entrevistadas, aqui são usadas teorias da etnomusicologia e da sociologia da música a fim de explorar as relações de significação entre produzir, distribuir e receber a música no contexto religioso das igrejas batistas: como os grupos se preparam e produzem as músicas (performance e criação) para o culto (produção); como eles atuam durante o culto (distribuição); como eles percebem e experienciam o que fazem (autorecepção).

No entanto, para o estudo dessa música que canta a Palavra, aqui em maiúscula por ser remetida nos discursos evangélicos como "palavra de Deus", ou da Palavra cantada, entra em jogo os discursos envolvidos nas produções do ambiente sonoro nos cultos estudados. Os discursos sobre suas histórias e formações; sobre as músicas; os cultos; as

entanto, faz-se necessária a diferenciação do pertencer ao mundo e do estar no mundo. Essa reflexão é feita a partir do texto do Evangelho de João 17:11-19. Todos os cristãos estão no mundo, mas não são do mundo, uma vez que, através do ideal de santidade (do hebraico, separação), eles devem se portar de forma diferenciada, observando princípios e valores segundo o modelo de Cristo, vendo este mundo como temporário, uma vez que se almeja a eternidade.

${ }^{4}$ Entendido como o corpo moral ético que liga igrejas de um mesmo pensamento. "Embora o termo seja historicamente derivado da Reforma Protestante, ele é usado mais geralmente para descrever corpos religiosos ou associações de congregações que estão unidas sob uma mesma proteção histórica e teológica" (Yamane, 2007:34)

${ }^{5}$ Esta e as demais traduções livres de textos estrangeiros são de minha autoria. 
igrejas; as doutrinas religiosas, proferidos pelos meus campo-objeto-sujeitos ${ }^{6}$, que em diálogo com a bibliografia consultada, transitam por um mundo carregado de instâncias e recortes segundo a vivência de cada um, a cultura em que estão inseridos e a forma como apreendem essa cultura. Tudo isso afeta de diferentes formas o discurso.

\begin{abstract}
Dada sua origem "comunitária", a fala de um sujeito é necessariamente vascularizada pelas vozes da cultura de que faz parte, dentro de uma sincronia em constante mutação [...] Nas palavras de Jacques Lacan, "enquanto é linguagem humana, nunca há univocidade do símbolo..." (Longo, 2006:9-10).
\end{abstract}

Assim, ao pretender, que não somente as minhas interpretações das falas de todos os entrevistados, mas, também que as próprias falas falem e transmitam significados, inerentes, delineados e ambíguos ${ }^{7}$, num jogo êmico/ético, é interessante notar que, para além de significados mutáveis, temos significantes excessivos e instáveis.

Significantes e significados são construídos e desconstruídos indefinidamente. "Nada tem um sentido intrínseco, natural. Toda realidade desperta suspeitas, desde a mais supostamente plena até a mais aparentemente caótica. Trata-se, em suma, de, diante de tais suspeitas quanto ao sentido de uma experiência, correr o risco de uma interpretação" (Moraes, 2002); as coisas se concentram em processamentos constantes.

Logo o que se pretende é, à luz dos discursos individuais sobre as vivências individuais/coletivas (o culto), observar a música, isto é, através do que se revelou no discurso, nas compreensões e vivências dos conceitos e corpos de regras, o que faz com que as músicas, nesses cultos, se apresentem como são; quais pensamentos justificam essas práticas musicais; que padrões - musicais e sociais - se estabelecem e qual o valor a eles é dado; o jogo de sagrado e profano, uma vez que "o que é sagrado atrai e possui um valor incomparável, mas, no mesmo instante isso parece vertiginosamente religioso para esse mundo claro e profano onde a humanidade situa seu domínio privilegiado" (Bataille, 1993:32). E finalmente, se "o canto ligado ao fenômeno religioso traz, na maioria das vezes, compatibilidade com os conteúdos de pensamento ou da teologia por trás dele" (Fatarelli, 2007:53), o que eles querem dizer quando cantam o que cantam, ou o que eles querem dizer quando dizem o que dizem?

\footnotetext{
6 "os sujeitos que constituem o campo-sujeito-objeto são, como os próprios analistas sociais, sujeitos capazes de compreender, de refletir e de agir fundamentados nessa compreensão e reflexão" (Thompson; 1995:359; grifo do autor). Meus campo-sujeito-objetos foram colaboradores não só em adição de dados, mas como fatores multiplicativos de reflexões e compreensões.

${ }^{7}$ Segundo a Teoria dos Significados Musicais de Lucy Green, 1988.
} 


\section{Olhando para os cultos: reflexos de luz na produção do som}

A forma como as lideranças musicais de cada igreja compreendem o espaço e as definições de culto, como se portam no espaço da igreja, como compreendem a música e como a fazem, é distinta em cada culto, na receptividade e reação das pessoas que cultuam, nas regras que regem todo o processo cúltico, e assim por diante. Para entendermos melhor as diferenças, tomemos alguns princípios históricos.

Desde os primórdios da Reforma, as grandes diferenças que encontraremos, nos diversos modos de ser cristão, estão explícitas, não somente, mas principalmente, na interpretação das escrituras, concepção da fé e relacionamento com as pessoas da Trindade. A livre interpretação da Bíblia passa a ser a marca dos protestantes no século XVI. Juntamente com essa interpretação, a autonomia das comunidades que a interpretavam, isto é, das igrejas, passa a ser uma marca dos batistas, como ressalta Mendonça: "os batistas com sua democracia direta e autonomia das congregações locais" (1995:191).

Os batistas chegaram ao Brasil no fim do séc. XIX, construindo uma história baseada no isolamento e conquista de território, com suas particularidades em relação às denominações anteriores. Como bem localizou Cunha (2004), os batistas se inserem no chamado Protestantismo de Missão, e é ao caráter desses missionários que se reporta toda uma tradição que aqui foi criada: "nitidamente norte-americana e caracteriza-se por ser uma doutrina a-histórica, acultural e sectária" (Teixeira apud Esperandio, 2005).

Com diferentes personalidades missionárias também vieram diferentes formas de se interpretar o 'ser batista' e de se ser este 'ser'. Assim, a história dos batistas é marcada profundamente por cisões e divisões.

\footnotetext{
É importante observar que as cisões nas igrejas batistas, motivadas por divergências de interpretação bíblica, estão presentes desde sua origem e acompanha todo o desenvolvimento de sua história, parecendo representar, desse modo, mais do que um traço que caracteriza esse grupo. A tendência às cisões estabelece-se como elemento que lhe é constitutivo. A "bibliocracia", aliada ao "livre exame das escrituras", e a forma de governo não hierarquizada, mas de congregações autônomas, possibilita com relativa facilidade e com grandes prejuízos à denominação, as incontáveis divisões advindas do exercício do livre exame das escrituras (Esperandio, 2005). ${ }^{8}$
}

\footnotetext{
${ }^{8}$ Como confirma Cunha: "Os missionários que implantaram o Protestantismo Histórico de Missões no Brasil adotaram uma espécie de uniformidade na propagação desses elementos da fé protestante (teologia,
} 
Destas cisões vieram os ramos pentecostais do ser batista. Conforme Magali Cunha relata, o Protestantismo de Renovação ou Carismático "surgiu a partir de expurgos e divisões das chamadas 'igrejas históricas', em especial na década de 60 , caracterizado por posturas influenciadas pela doutrina pentecostal" (2004:18). Dessa forma surgiu o 'ser batista renovado', ou 'ser batista pentecostal', em oposição ao 'ser batista tradicional', e, para além de simplesmente palavras, os sentidos contidos nelas transcende a diferenciação da práxis, interferindo diretamente na ontologia do ser batista: sua cosmologia e seu ethos.

$\mathrm{O}$ 'ser batista tradicional' se apega ao racionalismo, às normas ditadas pelo estatuto da igreja que freqüenta, aos formalismos religiosos e burocráticos (Hinings, 1973), se entregam a uma forma de ser caracterizada pela obrigação. O 'ser batista pentecostal', pelo próprio estilo de pentecostalismo adotado pelos batistas, se vê livre de muitas das regras formais e burocráticas, uma vez que, continuando como instituição a igreja terceiriza sua burocracia em nome de um culto que envolva mais os sentimentos, como se os membros estivessem enlaçados pela fé e desobrigados com relação a todo resto. $\mathrm{O}$ culto, o agora, é o que importa

Das observações que fiz na igreja batista tradicional (IBT), a impressão que tive foi a de estar olhando por um vidro claro e transparente. O ambiente sereno, o alto controle sobre todas as ações durante o culto, o silêncio, o caráter solene, as roupas de todos, discretas e sem cores ou cortes extravagantes, criavam um espaço sem grandes efeitos, constante e quase imutável de quem vê uma tela emoldurada com vidro e bem presa a uma parede. Quase imutável, a não ser pelos jogos de luz que batem no vidro que a emolduram, luz que dá nuances a essa cena: "para mim, ao menos, a cena é aquela aparência, a forma ou refração da situação 'objetiva' em que nos encontramos, colorindo-a ou nuançando-a e, com isso, tornando-a diferente daquilo que sabemos que ela é quando nos damos ao trabalho de sobre ela pensar objetivamente" (Crapanzano, 2005:35).

A sensação de estar olhando para uma tela, vem, creio eu, do modo como as coisas acontecem em IBT. A disposição de pessoas e instrumentos em diferentes cultos é quase inalterada: o pastor se assenta sempre no mesmo lugar, o regente congregacional rege da mesma estante, e ao que pude observar, as pessoas também costumam se

costumes, forma de culto), mas ao mesmo tempo mantiveram o espírito divisionista [...] a característica cismática e divisionista do protestantismo encontrou espaço no Brasil e provocou muitos conflitos. Havia concorrência entre as denominações, agravada pela passagem de fiéis e pastores de uma para outras e pelas polêmicas [...]" (2004:74). 
assentar nos mesmo lugares - ou muito próximos a estes - em que estiveram no culto anterior. O que difere esta cena do caráter fixo da tela é a sua constituição primeira: pessoas. Entretanto, as intenções dos discursos nessa igreja, que regem essas pessoas durante o culto, parecem querer ir à contramão dessa universal permanência da mudança, buscando assim uma constância em sua forma de ser. Talvez, a busca por ser uma 'tela imutável', ainda que utopicamente imutável, presa a parede de uma tradição que muitos acreditam não mudar, seja o desejo dos que ali estão.

Já na igreja batista pentecostal (IBP), o estilo livre do culto, sem grandes formulações prévias, se reflete no jeito de cultuar das pessoas. Da mesma forma como as músicas variam de estilo, variam os estilos das pessoas que estão ali: ao invés de ternos e trajes mais sociais, jeans e camiseta. Roupas coloridas, que se juntam aos jogos de luz e efeitos especiais durante o culto, dando-me a sensação de estar observando aquilo tudo como que por um cristal de prisma - aquele em que a luz passa e se desmembra em muitas cores.

Essa sensação de 'prisma' vem quando todos dançam ao som da música, movimentando seus corpos em resposta a um ritmo ou a um comando como 'bata palmas', 'grite comigo', numa interação e busca frenética de uma experiência que transcenda as trivialidades cotidianas, permitindo aflorar a emoção; saindo de um mundo outro para adentrar ao 'perigoso' mundo religioso-musical, no qual música é

(...) uma linguagem de emoções, através da qual nós experienciamos diretamente o ímpeto fundamental que move a humanidade... Uma arte perigosa... Mas sob orientação do intelecto e à luz do senso moral ela é certamente tão segura quanto qualquer coisa possa ser - tão segura... Quanto religião ou ciência. (Cooke apud Finnegan; 2003: 182).

Vejamos outras reflexões sobre cena.

Nenhum olhar é estável, ou antes, no sulcro neutro do olhar que trespassa a tela perpendicularmente, o sujeito e o objeto, o espectador e o modelo invertem seu papel ao infinito (...) Porque só vemos esse reverso, não sabemos quem somos nem o que fazemos. Somos vistos ou vemos? O pintor fixa atualmente um lugar que, de instante em instante, não cessa de mudar de conteúdo, de forma, de rosto, de identidade. Mas a imobilidade atenta dos olhos remete a uma outra direção, que eles já seguiram freqüentes vezes e que breve, sem dúvida alguma, vão retomar: a da tela imóvel sobre a qual se traça, está traçado, desde muito tempo e para sempre, um retrato que jamais se apagará. De sorte que o olhar soberano do pintor comanda um 
triângulo, que define em seu percurso esse quadro de um quadro: no vértice - único ponto visível - os olhos do artista; na base, de um lado, o lugar invisível do modelo, do outro, a figura provavelmente esboçada na tela virada (Foucault, 1981:21).

Em quê há de se pensar? Telas; olhares; instantes; eternidades; o pintor; o espectador; quem faz e é feito; o estático e o mutável; o infinito. A descrição da cena acima pode nos dizer algo sobre as cenas sobre as quais falo.

Em primeiro lugar, a mobilidade entre espectador e modelo que se invertem ao infinito. Essa mobilidade nos aponta efemeridade incontornável: nenhum objeto é, a priori, um objeto que não possa se tornar um sujeito quando se trata de um trabalho inserido nas chamadas Ciências Humanas. Nenhum livro, campo dos trabalhos teóricos, é um objeto sem ação sobre o sujeito que o lê; nenhum campo social, campos dos trabalhos de campo, são objetos em si. Nem mesmo uma tela, aquela que se pretende fixa e imutável, estática nas paredes da história, nem mesmo essa, é um objeto, mas antes, todos são sujeitos potenciais.

Em segundo lugar, vem os colocar como questão o papel do pintor, para mim ao menos, o do pesquisador - aquele do vértice, que mesmo não construindo a cena ativamente, é quem a recorta e a transforma em palavras. Talvez eu pretenda pensar aqui que esse artista/autor não como o vértice, mas como um desses vértices, como um dos pontos possíveis do visível. Mesmo porque, como pretendo tentar supor, o campo do invisível, da opacidade, do que não se deve revelar, se mostra bem mais frutífero do que aquilo que se pode simplesmente ver.

Em terceiro, temos a tela, a cena, resultado da confluência dos outros dois elementos - sujeito e pesquisador. Ao descrever as cenas lanço luz sobre elas. Ao lançar luz, aparecem sombras, posto que uma não existe sem a outra. A luz evidencia, a sombra esconde. Será mesmo? Pensemos na nossa luminária maior, o sol. Quando ele aparece, em toda sua clareza e fulgura, clareia muitas coisas, mas esconde tantas outras, tais como todas as constelações no céu, que só se mostram na sombra da noite antes do amanhecer. Então talvez tenhamos diferentes perspectivas a nossa frente: a luz mostra ao mesmo tempo em que esconde. O que significa que provavelmente eu não consiga determinações e classificações claras, mas antes, apontamentos sombreados, que a luz se encarregou de mostrar ou esconder.

Em determinadas superfícies a luz atravessa, em outras se desmembra ou se reflete. Tudo isso parece uma grande aula de física do Ensino Médio, e é relembrando essas 
aulas que volto às definições dos elementos que ecoaram em minha mente ao observar essas cenas rituais por mim descritas. O vidro é um óxido metálico transparente, "essencialmente" inerte; o prisma, um poliedro formado por uma face superior e uma inferior, paralelas e congruentes, usado para transformar um feixe de luz natural em luz polarizada. Ao observar essas definições, o vidro realmente me parece um bom objeto para falar de IBT, uma vez que ela parece ser mais transparente e 'essencialmente' inerte. Mas, observá-la somente como uma moldura vítrea me faz correr o perigo das distorções que a luz causa no vidro - talvez essa estaticidade seja uma dessas distorções.

O prisma polariza e conduz, segundo as suas propriedades, a luz que por ele passa. Veremos adiante, ao mencionar os elementos constituintes do culto, a transparência talvez possa ser relacionada à racionalidade de IBT, enquanto a polarização, à condução de uma linha músico-emocional em IBP, isso se olharmos os cultos como cenas opostas e coexistentes numa mesma sociedade mineira, que é "um universo caracterizado por uma pluralidade de vozes, paisagens [cenas] e de formas de organização" (Perez, 2000:2).

Se cada culto é uma cena, e posso interpretá-la como uma superfície de atuação de pessoas, parece-me pertinente voltar a Crapanzano (2005), e ver que na realidade, as questões que pretendo explorar são 'sombras que lançam luz' sobre minhas cenas. E nada mais interessante para observar uma cena, com seus jogos de luz e sombra, que o espelho, no qual, além de observar os outros, consigo me ver a observar esses outros. E o que é o espelho senão uma superfície muito lisa e com alto índice de reflexão da luz. No entanto, o fato de uma superfície refletora ser lisa não implica em que o que nela é refletido seja também liso. As cenas que se refletem no espelho da minha interpretação, ainda que se pretendam claras e transparentes, nem sempre o são.

Há imagens e sombras no espelho. As imagens são vistas, as sombras se escondem. As sombras estão lá, na superfície do espelho, mas não se enxergam com facilidade uma vez que há mais luz nas imagens do que nas sombras. Toda sombra no espelho significa, portanto, a presença de uma consciência que emerge do esforço para percebê-la (Lucas, 2001:4).

E no intuito de deixar revelar sombra e luz que, através da reflexão sobre como a liderança de cada igreja pensa e define suas próprias práticas de culto e música, permitirei que as cenas falem através de mim, por um mergulho em suas próprias superfícies. 


\section{Culto e cultura: o sagrado e o profano no ambiente musical}

Estamos aqui nos referindo a um sistema religioso, que, segundo Durkheim se “constitui de mitos, dogmas, crenças e ritos" (1996:18); um todo que só pode ser definido em relação as suas partes. Cada uma dessas igrejas, encerradas em si, cria um sistema, um 'mini-mundo', uma mini-sociedade circunscrita no território de uma sociedade mais ampla, de modo que, muitas das experiências no 'mini' são pautadas segundo as 'pressões' do macro. De forma mais explícita: IBT experiencia sua vida num debate com o meio batista tradicional ao qual pertence, do mesmo modo que IBP tem suas experiências em constantes diálogos com o meio pentecostal batista. No entanto, outras pressões despontam na vida de cada uma: as relações das igrejas com a mídia; as relações com o crescimento e ocupação do espaço 'urbano', personificado nas pessoas que nele transitam; enfim, o mundo com todos os conceitos e pré-conceitos sobre ser evangélico, sem deixar de mencionar as relações entre o 'sagrado' e o 'mundo' (profano).

Esses espaços cultuais de atuação pretendem ser analisados aqui como espaços culturais do imperativo jogo entre permanecer e transformar, no qual é pautada a tradição. Espaços que produzem formas padrões. No pensamento simmermiano

\footnotetext{
A idéia básica é a de que determinados padrões de interação destacamse dos conteúdos (sentimentos, impulsos, etc.) que de certo modo lhes davam vida e passam a operar por sua própria conta, como receptáculos para relações que se ajustem a eles. Isso permite pensar a sociedade não diretamente como um conjunto de interações em fluxo, mas como um conjunto de formas padronizadas (Cohn, 1998).
}

Aqui, no entanto, as formas padrões que parecem despontar, não vão ser analisadas como receptáculos exclusivamente, pois se pretende que não somente a forma, mas também o fluxo se mostre, em suas similaridades e diferenças, porque talvez encontremos "o valor da vida não naquilo que é atribuível igualmente para todos, mas sim no que lhe é particular e não esquemático" (Simmel, 2005).

Tratando o culto como uma forma para um fluxo de interações, abre-se a possibilidade de vitalização da forma, uma vez que o que se emprega são as vozes dos próprios sujeitos falando de si e de suas experiências. Talvez assim, colocadas no 
cotidiano do culto, as ações e reflexões se mostrem como relações ativas dos sujeitos com suas culturas, numa ampliação da perspectiva do espaço simbólico. ${ }^{9}$

IBT em cena

- Forma e formalismo

Culto é o encontro do homem com Deus. Do homem que tem o coração quebrantado, o coração agradecido. $E, \mathrm{em}$ reconhecimento ao que Deus tem feito na vida dele, ele vem à igreja pra adorar a Deus, pra agradecer, pra pedir. Em reconhecimento a grandeza de Deus, ele vem adorar (Miriam) ${ }^{10}$. É a hora da reunião dos crentes, daqueles que tem o mesmo pensamento de fé, e é a hora da comunhão com Deus e com os irmãos. É uma hora coletiva das pessoas que tem o mesmo pensamento, e vêm como demonstração pública, da sua adoração a Deus. Você pode adorar a Deus no seu quarto, ler a bíblia, mas agora é o seu momento de adorar a Deus numa demonstração pública e coletiva (Ester).

O básico é o quê? É você estar ali, como diz a Bíblia, dois ou três reunidos pra cultuar a Deus, pra elevar o pensamento a Deus, pra reconhecer a soberania Dele, que Ele é merecedor do nosso culto (Elizeu) [grifos meus].

A ação, a disposição e o modo de portar-se parecem ser pontos relevantes na forma de culto em IBT. Há espaços próprios para o culto, mediados física e não - fisicamente. O local físico do culto é tratado como sagrado e, o culto (não-físico) também deve ser considerado assim, uma vez que, como vemos nas falas dos músicos aqui, os verbos $i r$, vir e estar dão ênfase ao lugar e à atitude da pessoa em buscar esse lugar para cultuar: a pessoa vai à igreja, disposta a cultuar e porta-se de uma maneira diferenciada para adorar a Deus. Assim, a postura no culto pode ser pensada como algo com um quê de 'sagrado'.

Mas, por quais campos passam as definições de sagrado dessas pessoas? Essa pode ser uma discussão ampla e extensa, no entanto, me aportarei em Michel Leiris em seu Le sacré dans la vie quotidienne (1979), uma vez que estamos tratando de parte do cotidiano das pessoas aqui. Para o autor a categoria 'meu sagrado' é relevante. O sagrado é visto pela ótica da unicidade e experiência individual, cujos signos psicológicos são fatos, lugares e objetos que mesclam sentimentos e afloram o caráter ambíguo do atraente e do perigo - a potencialidade da emoção. A partir dessa

\footnotetext{
9 Pode-se pensar em estrutura, no entanto, ao longo do percurso fui advertida de que a idéia de estrutura leva a um sistema fechado, e significados e experiências são fluidez e vitalidade, mudança e abertura. Preferi pensar em forma, mesmo sabendo que há aqueles que pensam a forma quase como uma estrutura. ${ }^{10}$ Os nomes aqui mencionados, assim como as siglas IBP e IBT foram escolhidos como pseudônimos, com a finalidade de preservar a identidade dos meus campos-objetos-sujeitos.
} 
perspectiva de sagrado, principalmente da experiência individual, veremos que tal como indivíduos são diferentes, suas concepções de sagrado também se diferenciam. No entanto, a forma sócio-histórica por trás do culto acaba por estabelecer padrões nas definições do sagrado. Nos discursos dos músicos de IBT, e em suas práticas, alguns pontos podem ser observados como 'sacralizadores' do fluxo e da forma do culto: a racionalidade, a ordem, o respeito e a não relação com as 'coisas do mundo'.

- Ordem e racionalidade

$\mathrm{Na}$ interpretação batista da passagem bíblica de Romanos 12:1 ${ }^{11}$, a racionalidade, concebida explicitamente sobre a 'ordem' das coisas, tem valor central. Essa ordem e uso da razão podem ser verificados na forma rígida e impressa das ordens dos cultos: o racional poderia ser visto, assim, como o domínio sobre todos os elementos do culto (o controle) sob o recorte da organização e da previsibilidade.

\section{Forma do culto - IBT}

Processional Música que dá início ao momento de culto - enquanto ela é tocada, as pessoas tomam seus lugares e se preparam para o que se seguirá.

Avisos e Momento em que são dadas diretrizes e avisos com relação à
saudações aos programação interna da igreja e se verifica a presença de novas visitantes pessoas, não-membros dessa igreja, no culto.

Prelúdio Música que dá início ao culto propriamente dito, ou, em outras palavras, ao culto vertical: daqui em diante tudo que será feito diz respeito diretamente à relação Deus-fiéis.

Momento Não que este momento seja somente musical, mas é o lugar em que a
musical música aparece com maior evidência. Nele está contido o canto congregacional que acompanha o momento de entrega de dízimos e ofertas; a música instrumental que é tocada no momento de oração silenciosa; as músicas especiais (apresentadas pelos corais e conjuntos da igreja) que precedem a mensagem.

Mensagem A pregação do pastor, ou de alguma outra pessoa encarregada de falar baseada na Bíblia. Geralmente é finalizada com um hino à escolha do pregador e uma oração.

\footnotetext{
11 "Portanto, irmãos, rogo-lhes pelas misericórdias de Deus que se ofereçam em sacrifício vivo, santo e
} agradável a Deus; este é o culto racional e vocês" (Romanos 12:1). 


\begin{tabular}{|ll|}
\hline Poslúdio & $\begin{array}{l}\text { Uma música mais lenta, em caráter reflexivo, durante a qual as } \\
\text { pessoas, geralmente, fazem orações silenciosas. }\end{array}$ \\
\hline Recessional & Uma música mais 'animada' que indica o término efetivo do culto. As \\
& pessoas só se retiram do templo após o término dessa música. \\
\hline
\end{tabular}

TABELA 1: Forma do culto - IBT

Ao ser questionada sobre a ordem do culto, Ester, responsável pela elaboração dessa ordem, disse: "Procuro seguir o modelo do livro de Isaías, o modelo lá do capitulo 6, que fala que tem uma parte de adoração, uma parte de dedicação, essa seqüencia. Ai eu escolhos os hinos dentro do CC ou dentro do HCC ou de cânticos avulsos que encaixam nesses períodos, nessa ordem. E, leituras biblicas que tenham a ver com o que a gente está cantando".

Vamos à fonte, Isaías seis. Este não é um capítulo que fale sobre o ajuntamento de pessoas para um culto público, antes, fala do chamado e visão de um profeta no Antigo Testamento, no entanto, elementos encontrados nele são tratados como elementos essenciais para um culto.

\section{ISAÍAS seis: elementos do culto}

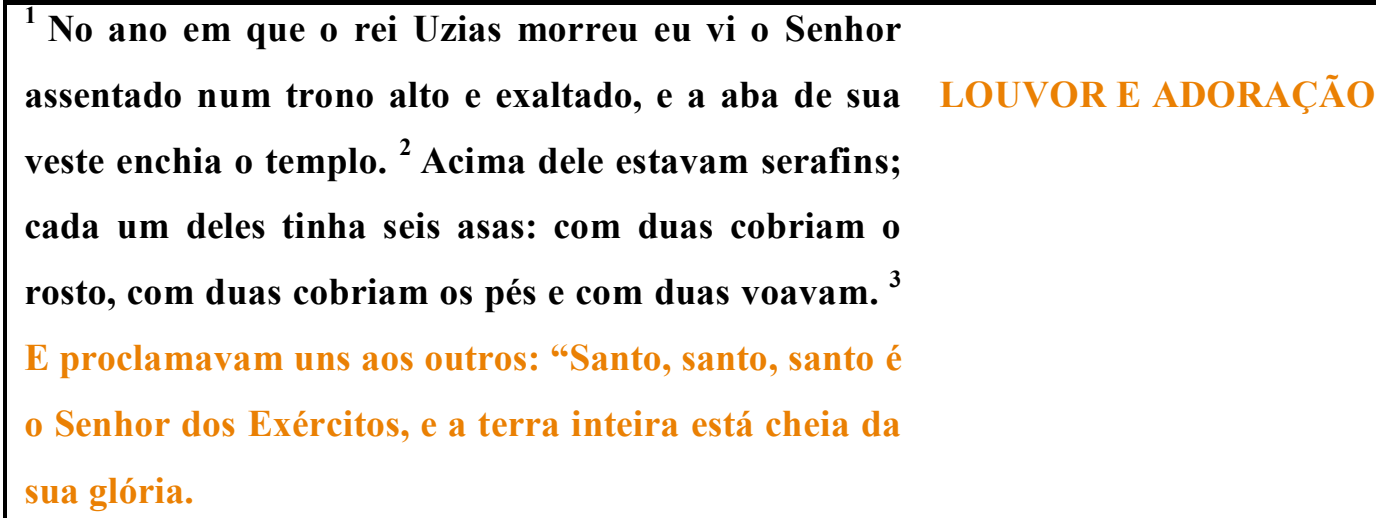

4 Ao som das suas vozes os batentes das portas bateram e o templo ficou cheio de fumaça. ${ }^{5}$ Então ORAÇÃO

gritei: Ai de mim! Estou perdido! Pois sou um homem de lábios impuros; os meus olhos viram o Rei, o Senhor dos Exércitos

${ }^{6}$ Logo um dos serafins voou até mim trazendo uma brasa viva, que havia tirado do altar com uma tenaz. CONTRIÇÃO

${ }^{7}$ Com ela tocou a minha boca e disse: ${ }^{6} \mathrm{Veja}$, isto tocou os seus lábios; por isso a sua culpa será 
removida, e o seu pecado será perdoado"

8 Então ouvi a voz do Senhor, conclamando: "Quem CONVOCAÇÃO enviarei? Quem irá por nós?"

E eu respondi: Eis-me aqui. Envia-me!

RESPOSTA

\section{TABELA 4: Elementos do culto com base no texto de Isaías 6:1-8.}

Estes elementos norteiam o culto da IBT, sendo possível fazer as seguintes ligações:

1) Apesar das palavras louvor e adoração não dizerem respeito somente à música, a música acaba sendo uma das formas mais práticas de suas expressões, como apontam alguns pensamentos e visões, como as de Playford, para o qual "o primeiro e supremo uso da Música é para o serviço e louvor de Deus, de quem ela é uma dádiva. O segundo uso é para o consolo dos homens" (apud Chase, 1957:7). Isso pode ser observado em textos bíblicos do Antigo e Novo Testamento, mostrando a extensão das práticas musicais na tradição cristã. Dessa forma poderíamos ligar diretamente o elemento "louvor e adoração" às práticas musicais no culto. ${ }^{13}$

2) A “oração" pode ser ligada a qualquer outro elemento do culto e colocada em qualquer parte da ordem. É usada como um meio de contato direto com Deus, logo, podemos ter: louvor e adoração - oração cantada; contrição - oração de arrependimento, entrega, súplica, etc.; resposta - oração de entrega. Como se pode observar na ordem de culto de IBT, a oração tem seus lugares bem especificados.

3) A "convocação" tem uma ligação direta com a mensagem, uma vez que o pastor fala da 'palavra de Deus' e 'em nome de Deus'.

4) A "resposta" pode ser observada como a própria atuação pessoal no culto, e o próprio culto, como uma resposta de fé que o fiel demonstra a seu Deus. A "resposta" também se liga à parte de dedicação de bens e ofertas, resposta material em agradecimento e/ou obrigação do crente para com a igreja e para com Deus.

Percebemos que a estrutura se conecta ao discurso, forma e fluxo se completam, o modelo seguido se encaixa ao modelo impresso como meio de expressão da

\footnotetext{
${ }^{12}$ A interpretação que permite a retirada desses elementos é corrente no meio batista. Essa tabela foi elaborada a partir de uma aula de Antigo Testamento, ministrada pelo Prof. Tarcísio Araújo Caixeta, em 2004 no curso de Teologia da Faculdade Batista Mineira.

${ }^{13}$ Como exemplos: Salmos 150; Colossenses 3:16.
} 
racionalidade. O racional pode ser definido pela interpretação bíblica colocada em termos de ordem litúrgica, aqui fixa e previsível.

- A reverência e o mundo

Citando o Estatuto que rege a IBT, cabe aqui salientar:

Seç̧ão I - Art. 43: O culto congregacional será solene e reverente, obedecerá à ordem de culto que tiver sido anteriormente preparada [já indicador de previsibilidade], não admitirá particularismos, manifestações de apreço ou outras idiossincrasias quaisquer [como falar Aleluias e Améns em voz alta, glossolalia, etc.], que possam incomodar, perturbar, constranger ou inibir a ação de graças de outrem.

O respeito para com o lugar enquanto sacro e para com os outros que estão ali cultuando, está diretamente ligado à postura reverente que cada um deve ter em culto. Este respeito também pode ser observado com relação à 'tradição batista'. O formalismo que IBT optou por seguir preza, segundo seu discurso e sua práxis, manter uma tradição batista que veio com os missionários: a forma de culto, os hinários, até mesmo a formato de seu espaço fixo e vestimenta dos condutores do culto - terno e gravata. Manter esses padrões parece refletir uma não concordância com o mundo, que seria definido como tudo que não é sagrado em suas práticas, e a não aceitação (ou crítica) de outras denominações que permitem idiossincrasias explícitas.

Em um diálogo com a contemporaneidade, ou seja, com o território social mais amplo que abriga essa igreja (a mídia, a política, as outras denominações religiosas), IBT matem firme sua postura frente às pressões de uma transitividade da experiência religiosa, de um "sagrado sem lugar" (Amaral, 2003:104), enfatizando sua crença “classificação das coisas, reais ou idéias" (Durkheim, 1996:19) - no dual sacro-profano.

- Música: o lugar de explicitação do sagrado e do profano

O que vem acontecendo é que a música tem sido utilizada de maneira distorcida nas igrejas e nos ditos meios evangélicos, proporcionando mais "status" àqueles que cantam, tocam, interpretam e deixando de lado àquele a quem estão oferecendo o louvor: Deus (Deborah).

Tudo aqui na igreja é sempre com partitura. Nunca aqui se usa só cifra não [...] Uma vez eu apresentei um baião com o coro infantil e eles falaram pra não tocar mais. 'Muito bonita a música, mas não cante mais'. Então tem limitações. Palmas, louvor com brados e aleluias, essas coisas também não, porque na igreja, a maioria dos membros optou por não ter esse tipo de coisa. Aqui nós somos mais dos hinos, da música mais séria; bela, mas séria. Nada popular. Entra algum popular através de cânticos que a gente traz, mas sempre muito bem selecionado, o texto é bem selecionado. Guitarra, por exemplo, nós não usamos, o pessoal não gosta. Usa um baixo, mas esse contrabaixo faz a base mesmo, nada de extravagante (Miriam).

A gente também evita determinados estilos, samba, coisas muito assim, que chama muito a atenção mundana, que tem relação com o mundo a 
gente evita. Ritmos que tem correlação com o mundo a gente evita usar. E a gente dá uma atenção especial pra letra, pra num ter nenhum erro teológico [...]. A igreja não comporta a bateria. Existem pessoas que realmente não gostam desses instrumentos de percussão. Existem alguns preconceitos (Ester).

Sabe quando Deus fala na biblia: "afasta de mim os estrépitos com seus cânticos". Por quê? Porque é aquele cântico tão barulhento que não está agradando a Deus. Não porque ele seja barulhento. Ainda que ele seja barulhento, maravilhoso, ou uma orquestra, que tem coisas maravilhosas, se ele não for feito de coração ele não está agradando a Deus (Elizeu) [grifos meus].

Como dito anteriormente, as igrejas chamadas 'históricas' ou 'tradicionais' estão ligadas mais diretamente ao pensamento original da Reforma Protestante. Então, voltemos ao que era feito naquela época.

[...] Burke cita outro exemplo de Lutero, que foi a organização de uma coletânea de hinos "para dar aos jovens... algo que os afaste das baladas de amor e versos carnais, e ensine-lhes algo de valor em lugar destes". Lutero escreveu 37 hinos, o que foi seguido por outros pastores na Alemanha. Ao compor eles empregavam o método do que Lutero denominou contrafação, que tinha o sentido de transposição ou substituição, como nos casos em que as melodias dos hinos eram canções populares adaptadas (Cunha, 2004:158) [grifo meu].

E ainda:

Os reformadores designavam o estilo ao qual se opunham como 'a maneira usual', ou 'a maneira comum' de cantar. O estilo que defendiam era por eles denominado 'Canto Regular', ou 'Canto por Nota'. Cada um dos dois campos, é claro, tinha plena convicção da superioridade do seu estilo. No entanto, nada indica que os adeptos da 'maneira comum' procurassem impor aos outros as suas convicções, ou seus métodos. Queriam simplesmente, que os deixassem cantar em paz conforme lhes aprouvesse. Os reformadores é que, animados de vistoso zelo, pretendiam impor a toda a gente os seus padrões (Chase, 1957:2122) [grifo meu].

Lutero iniciou uma prática de compor e seus hinos, prática essa que seria imposta como padrão aos protestantes, tornando os hinos do protestantismo conhecidos sob o termo 'hinos luteranos'. O centro da discussão aqui, no entanto, não é ainda a forma padrão desses hinos, antes, ao cenário no qual eles foram compostos séculos atrás. Contrafação e imposição são as palavras de ordem. Melodias de canções populares foram fontes primárias para as composições de Lutero. Ao que parece, a 'sacralidade' buscada na música para aqueles cultos residia mais na letra que nos sons propriamente ditos. A partir do momento em que se colocava uma letra 'sacra' numa melodia 
conhecida, efetivava-se uma comunicação mais eficaz, uma vez que a melodia já 'estava no ouvido' do povo, e este voltaria sua atenção para a letra. O que foi popular outrora se cristalizou em partituras e coletâneas, e foi imposto, pelos reformadores e seus sucessores, como o melhor a ser seguido. Desta forma, concordo com Mendonça quando ele enfatiza: "Não nos resta, portanto, outro documento que expresse a resposta e a organização da crença por parte do protestante comum a não ser o seu livro de cânticos sagrados [...]" $(1995: 220){ }^{14}$

A crença na racionalidade expressa na ordem, e mais ainda, na cristalização de elementos dessa ordem, pode ser lida, ainda que nas entrelinhas, desde a Reforma. Contudo, como mudam as pessoas e o tempo, mudam as idéias e os valores impostos sobre essa ordem. Ao dizer "nós somos mais dos hinos, da música séria” um membro da igreja parece refletir, nesta fala, a ideologia vigente: 'somos, cremos e cantamos uma tradição que se impôs como padrão séculos atrás'.

Essa identidade proposta para a música evangélica, separada do mundo irá referir-se, de início, a não utilização dos instrumentos elétricos e eletrônicos (guitarra e o sintetizador), à bateria e os instrumentos de percussão, pela ênfase rítmica e pela analogia de estilos musicais que traziam à lembrança os padrões comportamentais e de vestuários inerentes ao artista popular (Souza, Z. 2003).

Ao assumir "nada popular" um muro contra 'o mundo lá de fora' é criado. Ainda que nesse muro haja as brechas dos cânticos avulsos, essas são brechas controladas, 'populares' não em sua completude, uma vez que vão se cristalizando no formalismo. Abri-se mão de criar coisas novas que fogem aos padrões estabelecidos para se manter uma tradição que se pensa fixa. Lutero usou o popular como inspiração, transformandoo no que hoje é conhecido como parte da música sacra protestante (com caráter mais erudito). IBT usa essa música que tornou-se 'sacra', mas, no entanto, acaba condenado em seus discursos os que se valem desse mesmo princípio de 'contrafação' nos dias atuais, não só com relação a melodias mas também a estilos e ritmos: "ritmos que tem correlação com o mundo a gente evita usar". O que musicalmente entra de "popular através dos cânticos" deve possuir um texto tão correto, de forma tal que esse se sobreponha a música, ou seja, à melodia e ritmos que dão suporte a esse texto.

\footnotetext{
${ }^{14}$ Ainda que, em sua definição ligada ao direito de autoria (Artigo 5º. VII, da Lei 9610/98) contrafação seja definida como a reprodução não autorizada de algo, na prática observada aqui, ela acaba sendo encarada como a utilização não autorizada de uma obra, ou, mais essencialmente, uma substituição de partes de uma obra para seu uso com outros significados, confundindo-se talvez com o plágio.
} 
Reconheço, no entanto, a importância de se ter em mente a diferenciação do popular nos tempos de Lutero e do popular na sociedade contemporânea. Conforme Araújo:

Essa referência à expressão "música popular" requer, porém, um breve comentário. Nos termos de Antonio Gramsci, ela seria considerada como segmento de uma cultura nacional-popular, expressão dos antagonismos entre classes sociais em uma sociedade nacional particular. A este conceito é contraposto aquele que Ortiz (1988) denominou cultura internacional-popular. Esta última "nasce, circula e é consumida como mercadoria lançada simultaneamente em diferentes mercados nacionais, simultaneamente [sic] internacional" (Ianni 1992: 49) (Araújo, 1996).

Apesar das diferenças, tanto o 'nacionalista' - sejam estes simples ritmos regionais brasileiros, como o samba ou o baião exemplificado por Miriam - quanto o 'artista pop de mídia', sugerido por Deborah, parecem entrar nessa concepção de 'popular' para a liderança musical de IBT - estejam estes dentro ou fora do chamado mundo gospel.

É possível dizer que o movimento gospel se apropriou, sem restrição, de coisas “mundanas" para a divulgação religiosa, e mesmo como 'alternativa criativa à música sacra evangélica', talvez como uma forma de contracultura evangélica, muito aliada ao pentecostalismo. Pode-se observar essa cena pelo recorte das idéias de IBT aqui já expostas: ao assumir 'ritmos correlatos ao mundo', há uma 'distorção na maneira de as igrejas usarem a música'; a ligação com a mídia gera o 'status' artístico, e podem vir questões tais como: 'isto está sendo feito de coração para Deus?'. Ainda que de forma velada em suas falas, o que a liderança musical de IBT parece passar, em sua prática, para o restante da igreja, é que suas formas cultuais e culturais, apoiadas em sua tradição musical são as corretas no que tange a sacralidade, reverência e racionalidade na comunicação igreja-Deus. O julgamento entre duais - certo/errado, sacro/profano, pode/não pode, sim/não, ou isso/ou aquilo - pode ser visto como o centro praxial de IBT, de forma que esta cria seus fiéis em uma tradição que luta contra as adaptações e pressões contemporâneas a respeito de cultuar, cantar e ser evangélico atualmente.

IBP em cena

\section{- Um outro (in)formalismo}

Culto pra mim na igreja é o momento de celebração. Você vai pro culto pra celebrar, você vai pro culto pra ter este tempo com Deus. Onde você agradece, onde você pede, onde você canta. Mas eu creio que nossa vida deve ser um culto, um culto sempre. Tudo que a gente faz deve ser pra agradar a Deus (Davi).

Nós cristãos, a gente acredita que nossa vida é um culto a Deus, não somente aqui, nessas 2 horas de reunião que chama culto (Mateus) 
Acho que o culto é essa coisa da comunhão. Porque se não, todo mundo ficava em casa de boa. Acho que uma das coisas mais importantes no culto é isso, esse lance da comunhão debaixo de uma liderança (Paulo)

É o momento que você está ali pra se entregar mesmo, pra você se dar. Você está cultuando, você está se dando, se entregando (Josué).

Jesus veio, rasgou o véu, é a nossa vida. Eu não me preparo, eu vivo o culto. [...] Quando a igreja recebe a música e participa, você vê que está dando tudo certo. Agora, quando você vê que o pessoal está se dispersando é porque tem alguma coisa errada. $A$ igreja é o termômetro, por ela que você vê. [...] Eu não consigo distinguir onde começa minha vida, onde começa o culto e onde começa a música (Salomão) [grifos meus].

O culto, para além de ritual em espaço físico, expande-se, na visão da liderança de IBP, para uma postura de vida. Não que a liderança de IBT não tenha essa mesma visão, no entanto, o que evidencia a postura de vida é a prática no próprio locus do culto. É possível observar como as posturas em IBP não se excluem, mas se complementam. Os verbos relacionados ao culto aqui são muitos semelhantes ao da outra igreja - estar, ir e vir - o que chama atenção, no entanto, são os verbos ser e viver. A pessoa está no culto, vai cultuar, no entanto, sua própria vida é um culto. Não se trata de estar no culto ou viver um culto, mas sim de estar no culto $e$ viver um culto. Essa visão e prática ampliadas proporcionam uma liberdade (in)formal do culto, que terá como seus principais elementos os mesmos retirados do texto de Isaías 6, contudo, sem uma ordem necessariamente pré-estabelecida. Linha emocional, interação com a igreja e improvisação marcam os cultos sob essa liderança.

\section{- Improvisação e espontaneidade}

A espontaneidade passa a ser marca dos pentecostais, que passa a ser imitada por muitas igrejas da tradição histórica. Segundo Cunha (2004:113-114), a centralidade da música e a técnica da espontaneidade configuram o espaço pentecostal como voltado para o 'espetáculo', inserido numa comunicação de mídia, muitas das vezes aliada à produção e comunicação de massa. Mas em que medida essa espontaneidade, é de fato espontânea? Cohn diz que "nenhuma regulamentação normativa ou legal pode substituir inteiramente os sentimentos que brotam espontaneamente nos homens nas suas aproximações e afastamentos recíprocos" (1998). De fato, regulamentações e sentimentos espontâneos transitam em diferentes sistemas operacionais, mas talvez o que seja interessante de se observar aqui é como se assegura, na forma do culto, a continuação 'formal' da espontaneidade. 
Ao contrário de IBT, as ordens dos cultos não são impressas e nem passadas com antecedência aos que participarão ativamente no culto. Pelo fato de ser líder musical do grupo e também pastor, Davi é quem prepara as 'ordens' de culto, e como os músicos que tocam com ele o acompanham constantemente em turnês, a ordem das músicas é passada minutos antes do início do culto.

Ao ser questionado sobre esse preparo, ele disse:

O culto existe principalmente pra gente não perder a motivação. Porque uma vez que a gente começa a receber por tudo que faz a gente quer receber por tudo o que faz. Mas a igreja é diferente, ali nós somos voluntários, nós não recebemos. O culto serve pra gente estar ali servindo. Toda terça é um desafio pra gente, porque a gente viaja muito. E o preparo pro culto é muito simples. $O$ que eu faço? Eu preparo uma mensagem que é uma reflexão na bíblia, uma reflexão pro nosso dia-a-dia, pra nossa caminhada, e dentro dessa reflexão eu preparo canções que vão preparar o coração das pessoas para ouvir aquela mensagem. A mensagem e a música no meu caso andam muito juntas. A mensagem e a música vão passar a mesma realidade (Davi).

Se ele prepara antecipadamente as ordens, então ele não improvisa? Do latim, improvisu significa fazer sem preparação prévia. Em música, no entanto, esse conceito se expande e pretendo usar dessa expansão para analisar a (in)formalidade nos cultos de IBP. Segundo Nettl (s.d.), uma das definições de improvisar seria uma elaboração ou ajuste numa estrutura já existente. Na forma do culto, como já vimos anteriormente, deveriam estar contidos: louvor, mensagem, oração e dedicação. Estes elementos estão presentes no culto de IBP, mas não em uma ordem definida. Para esclarecer esses ajustes formais, comparo diferentes cultos.

\section{COMPARAÇÃO DOS CULTOS - IBP}

\begin{tabular}{|c|c|c|}
\hline $11 / 09 / 2007$ & 02/10/2007 & $30 / 11 / 2007$ \\
\hline Música de fundo - oração & Música cantada 1 & $\begin{array}{l}\text { Música de fundo - } \\
\text { oração }\end{array}$ \\
\hline Espontâneo & Espontâneo & Música cantada 1 \\
\hline Música cantada 1 & Música cantada 2 & Música cantada 2 \\
\hline Música cantada 2 & Música cantada 3 & Oração \\
\hline Música cantada 3 & Música cantada 4 & Música cantada 3 \\
\hline Música cantada 4 & Música cantada 5 & Espontâneo \\
\hline
\end{tabular}




\begin{tabular}{|c|c|c|}
\hline Espontâneo & Espontâneo & Música cantada 4 \\
\hline $\begin{array}{l}\text { Música cantada } 5 \\
\text { Dedicação de dízimos e } \\
\text { ofertas }\end{array}$ & Música cantada 6 & $\begin{array}{l}\text { Música cantada } 5 \\
\text { Dedicação de dízimos e } \\
\text { ofertas }\end{array}$ \\
\hline $\begin{array}{l}\text { Mensagem (com música } \\
\text { de fundo) }\end{array}$ & Oração & Espontâneo \\
\hline Música cantada 6 & $\begin{array}{l}\text { Mensagem (com música } \\
\text { de fundo) }\end{array}$ & $\begin{array}{l}\text { Mensagem (outro } \\
\text { pastor) }\end{array}$ \\
\hline \multirow[t]{2}{*}{$\begin{array}{l}\text { Nota: Espontâneo foi } \\
\text { definido pelo próprio grupo } \\
\text { como uma oração cantada. }\end{array}$} & $\begin{array}{l}\text { Música cantada } 6 \\
\text { Dedicação de dízimos e } \\
\text { ofertas (música especial } \\
\text { cantada por outro grupo) }\end{array}$ & Oração de apelo \\
\hline & $\begin{array}{l}\text { Música cantada } 7 \text { (música } \\
\text { cantada por outro grupo) }\end{array}$ & Música cantada 6 \\
\hline
\end{tabular}

TABELA 3: Comparação entre cultos em IBP ${ }^{15}$

A forma do culto mostra-se maleável, permitindo improvisos e ajustes quando necessários, pois, mesmo não institucionalizadas através de um estatuto, as idéias de interação com a igreja e liberdade de culto através da 'ação' do Espírito Santo é marca de muitas igrejas em diferentes denominações pentecostais ou neopentecostais; uma vez que, uma das 'bandeiras' desses movimentos, vindos dos 'revivals' norte americanos, é ir contra a cultura rígida dos evangélicos 'tradicionais'. Mas em que medida essa tentativa de uma contra-forma é de fato algo sem forma? Em nenhuma medida. Pois se percebermos bem na tabela acima, ainda que com pequenos ajustes, a não-forma assume uma formalidade, que se pretende (in)formal na busca por uma linha de resposta emocional da igreja.

- A linha músico-emocional de interação

"Os cultos pentecostais têm um ethos, um espírito e uma estrutura emocional distintas. Cultos emocionais são feitos de um sistema normativo de emoções e comportamentos que operam durante o curso do ritual religioso" (Nelson apud Miller \& Strongman, 2002:8). Nesse campo normativo de emoções está o cerne do pentecostalismo, no entanto, este é posto em prática de diferentes formas em diferentes

\footnotetext{
15 Para a qual as cores correspondem aos elementos: DEDICA ÇÃ O MENSA GEM.
} 
igrejas. Umas procuram essa experiência emocional através de orações e falas altas, aliadas a jejuns, outras através de mensagens com pregadores 'inspirados' pelo Espírito Santo, outros se utilizam da música (Souza, A., 2005).

Observar a comparação de diferentes cultos em IBP revela a importância da música nesses espaços, dada à sua presença quase ininterrupta, que pode ser entendida como uma facilitadora na comunicação. A música dita a ordem do culto e integraliza liderança e liderados na busca de algo comum: Deus.

\begin{abstract}
Eu gosto da música porque ela preenche o vazio, ela preenche o espaço. Quando você fala tem muito vazio. Quando o tecladista me acompanha na mensagem, se eu falo algo mais forte ele toca mais forte, se eu falo algo mais delicado, ele toca mais delicado, assim, agrega tudo [...]. Já teve culto que a primeira música foi o ápice do culto. Tem momentos que a primeira música foi o boom, e o restante... Bom, já foi o que precisava. Como tem culto que a última foi o máximo, ou o meio. Isso vem. Eu vou lá pra igreja pra buscar a Deus, igual a todo mundo. Eu num vou pra igreja, num faço música, num falo de Jesus pra dar lição de moral. Tem momentos que todo mundo fica animado e agitado e há aquele ápice. Num é nada programado (Davi).
\end{abstract}

As concepções de igreja como 'cozinha de casa' ou como 'termômetro' e a ligação dessas idéias com a prática musical apontam para um ambiente descontraído e receptivo, e a meu ver, musicalmente construído, no qual a música é vista como sentimento em si, e também produtora e comunicadora de sentimentos. A interação da congregação com essa música - seja cantada, em forma de espontâneo ou como complemento da mensagem, determina a qualidade de um culto. Esses músicos que estão à frente do culto controlam, ou, buscam um controle, dos meios materiais e simbólicos - aqui: a música, as letras, bem como os demais discursos que as acompanham - que se aliam ao contexto, criando significados além da emoção somente. E ainda, esse controle é o que torna a pretensão de informalidade em formalidade, um sagrado domesticado nos termos de Bastide (O sagrado selvagem, 1992).

Se está no momento de adoração, todo mundo num momento adorando, e você do nada começa a fazer uma música agitada, você quebra a essência, você sai da essência, a essência passa a num ser mais aquilo, passa a ser só música. Então a gente começa primeiro com a música, com a questão musical do negócio, pra depois passar pra questão espiritual, como se fosse o tabernáculo. Tem o lugar do incensário, o lugar santo e o lugar santíssimo.Começa primeiro na música de fundo com uma palavra uma oração, que seria o lugar do incensário. Ai você entra pro lugar santo. Começou a música, um pouquinho mais 
agitada, que já te leva pra uma questão um pouco mais espiritual. E o lugar santíssimo, que é a hora que começa aquela música totalmente espiritual. Que num vai ter aquela complexidade harmônica, nem rítmica. Ela vai realmente proporcionar um estado de... Num é repouso... Encontro... A música tem esse poder né, de te levar até Deus (Pedro). ${ }^{16}$

Então, se você predispõe uma harmonia, um enredo musical que vá conduzir a emoção das pessoas, o tempo todo, então você vai conseguir prender a atenção delas. Música, teatro, a arte, ela lida com as emoções. Se você coloca uma luz que liga na hora exata, que apaga na hora certa, uma fumacinha que sai quando tem que sair, isso é arte, é pra prender a atenção. Nada pode ser feito sem propósito. Tudo tem um propósito: a altura dos instrumentos, a luz, a mixagem. É tudo feito pra emocionar as pessoas. Não pra emocionar assim, fingindo pra que elas pensem que está tudo bem. É como um óleo no motor de um carro, pra facilitar o que a gente tá querendo passar. Tudo é um artifício (Salomão).

Há uma consciência assumida da centralidade da música no culto. Ela constrói o espaço de atuação da liderança; não o espaço físico, mas o espaço existencial do culto, onde ocorrem as trocas horizontais - da comunhão entre pessoas de uma mesma fé - e verticais - das pessoas com o transcendente. Atrevo-me a pensar a música nos cultos sob essa liderança em IBP um pouco além. Ao contrário de 'óleo no motor de um carro', vejo-a como o próprio 'motor do carro' - aquela sem a qual o culto não 'se movimenta'. Através dela, a liderança prende a atenção do público durante o culto, interage com esse público e busca levar o público a um processo de 'adoração'. Essa atitude de 'prender' musicalmente a atenção de adoradores é confirmada por Sloboda (2000) como característica em muitos tipos de cultos. 'Tudo é um artifício' para se chegar aos objetivos propostos pelo ato de cultuar: interagir social e transcendentalmente.

Os músicos que aqui buscam essa interação, todavia, compreendem que quanto mais 'próxima' do contexto social formador daquele público for a música, maior será a potencialidade desta em comunicar e construir o espaço do culto. Para isso o 'sacro formal', que outrora vimos em IBT, será visto de outra forma, bem como o olhar sobre 'as coisas do mundo' será diferenciado.

- Música: um lugar de outras diferenciações entre sacro e profano

\footnotetext{
${ }^{16}$ Aqui, Pedro faz referência direta à estrutura arquitetônica do Templo dos judeus em Jerusalém, descrito no Antigo Testamento.
} 
[...] muitas pessoas em nossa cultura associam música de órgão com cenários de adoração (como resultado da experiência de cenários de adoração anteriores envolvendo música de órgão), mas não associam a música pop; música de órgão parece apresentar em si o 'sacro' e música pop, 'profano' [...] (Sloboda, 2000:114)

A música no culto de IBP está inserida na cultura pop, aquela do 'american way of life’. Ritmos, estilos, instrumentações e formas se mesclam para construir músicas classificadas pelo mercado como 'gospel', que, como dito anteriormente, parece ter se apropriado das 'coisas mundanas' nas visões mais 'tradicionais', dando uma amplitude ao conceito de sagrado, ou criando outra categoria de sagrado.

Esta nova categoria é reflexo do movimento crescente do mercado evangélico: os artistas, como qualquer outro, possuem uma carreira, gravam discos, apresentam espetáculos, cobram cachê, recebem prêmios, possuem fãs-clubes e ditam moda. No entanto, para eles e seu público, um aspecto distingue o mercado religioso do secular: esses artistas e suas músicas são mediadores do sagrado, ou, na linguagem popularizada no cenário evangélico, são “instrumentos de Deus” (Cunha, 2004:148).

Um sagrado no qual, musicalmente, se pode tudo:

Pode tudo. Porque assim, num existe uma regra. A música está aí para ser feita, cada um expressa os sentimentos que tem da forma que quer. Vamos fazer música, 'música música'. Num é fazer barulho, num é fazer só notas, é fazer música. Música se faz com sentimento. Música é sentimento, é arte, você se expressa através da música (Mateus).

Musicalmente se pode tudo, pois tudo vem de Deus:

O diabo não cria nada, ele não sabe criar nada. Deus é o criador de todas as coisas. O diabo nada mais fez do que roubar. Quando ele se rebelou contra Deus e levou 1/3 dos anjos, ele era o anjo da música, ele levava a música ao trono de Deus, então ele levou algo que Deus criou. A essência da música, a essência das melodias, elas vêm do coração de Deus. Então, não há, na nossa concepção, uma melodia que seja satânica, um som que vem do inferno. Mas não existe nada fora da igreja que a gente precise receber, precise se alimentar, nós temos em nós a fonte. Então, o que a gente passa pra igreja é que ela desenvolva os dons, desenvolva a musicalidade e aprenda a levar isso pra Deus sem precisar se comparar com quem é de fora, sem precisar olhar pra o que é de fora (Davi) 
No entanto, essa sacralidade imanente da música e essa liberdade de expressão musical no culto devem estar aliadas ao que o grupo deseja passar e ao que a igreja deseja receber (mecanismos de controle da 'forma' do culto), para que o culto horizontal, a comunhão com os irmãos, e a relação de respeito entre eles não seja quebrada, e para que se atinja o objetivo de levar a igreja a adorar:

Hoje você pode tocar tudo, você pode tocar rap, raggae, samba, funk. Antes não, tinha estilos pré-definidos e você num podia mudar, tocar nada diferente daquilo. Você pode usar efeitos, elementos mais fortes, guitarra, rock e tal. Agora, o que a gente sempre comenta no grupo e tenta estabelecer como prioridade é o nosso relacionamento, independente do que cada um gosta de tocar, nós temos que respeitar todos. O tempo todo a música mexe com o sentimento das pessoas, e você pode gerar intenções através da música. Se você toca uma música falando: vamos adorar, vamos celebrar, vamos glorificar a Deus, as pessoas vão fazer aquilo. Mas se você toca falando outras, elas vão fazer... Mesmo na igreja, às vezes as pessoas extrapolam os limites (Salomão).

Ao enfatizar 'antes', o grupo parece se colocar no 'agora'. O antes equivale a igrejas que, como IBT, escolhem (e zelam para que isso permaneça) estar presas em estilos prédefinidos de culto, de música e de ser batista, e se pensamos na própria história de IBP, antes, ela era da linhagem tradicional. O agora, entretanto, se abre, expande seus limites e conceitos para alcançar um público maior, um crescimento e uma visibilidade nos meios de comunicação, uma tradição criativa, que parece entender que a tradição consiste numa permanência na mudança - criação e recriação de conceitos, formas que se adaptam conforme as necessidades e desejos das pessoas que a constituem.

\section{Outras análises musicais}

Duas formas de cultuar, formal e (in)formalmente, mostraram-se muito próximas, se vistas pelo prisma do controle das ações em culto. Aqui, talvez as análises musicais nos confirmem essas semelhanças, e talvez as performances nos mostrem as diferenças finas que fazem com que as similaridades dêem mais lugar à diferença.

As músicas observadas neste trabalho transitam em ambientes ligados à música européia - canonizada pela Academia, construída num sistema tonal com caminhos harmônicos previsíveis e descritos em regras, sendo, muitas vezes, a melodia mais valorizada que o ritmo (Blum, 1992) e possuindo formas também já previamente definidas e determinadas - e em outros da chamada música pop, que também respeita regras de forma e harmonia, porém trata-as com mais flexibilidade, ou melhor dizendo, 
trabalha de outros modos as questões formais e harmônicas. Assim, o que interessa aqui é a maneira como, em cada contexto de culto, esses elementos já conhecidos vão ser tratados e interpretados.

- Formas musicais

Cada música que ouvimos possui uma lógica interna própria, e cujos significados vão ser atribuídos de diferentes formas a cada escuta. Essa lógica geralmente é identificada pelos elementos de repetição e contraste: o que é percebido como igual ou diferente. Como tanto em IBP quanto em IBT o material sonoro é complementado por uma letra, esses elementos de repetição e contraste são facilmente identificados e combinados nas seguintes possibilidades: a estrutura musical permanece e a letra muda; a letra permanece e a música muda; ambas mudam, ou permanecem.

Analisando o hinário oficial de IBT - Cantor Cristão - vemos que, formalmente, uma boa parte dos hinos possui duas partes, a saber, estrofe e refrão, característica adotada desde os tempos de Lutero. Essa forma pode ser classificada como binária simples. No entanto, ainda que musicalmente uma forma binária simples, textualmente ela será um binário cíclico. Se chamarmos a estrofe de $\mathrm{X}$ e o refrão (estribilho) de $\mathrm{Y}$, musicalmente teremos a forma X-Y. Ao considerar o texto, veremos que X se altera, uma vez que o texto nele muda a cada estrofe; Y, todavia, permanece igual. Assim, teremos uma forma final $\mathbf{X}-\mathbf{Y}-\mathbf{X}^{\prime}-\mathbf{Y}-\mathbf{X}^{\prime}$ ' $-\mathbf{Y}$, na qual o sinal (') indica a mudança textual que vai se repetir conforme a quantidade de estrofes de cada hino.

Como já dito anteriormente, são formas simples, para melodias simples e sem grandes rebuscamentos harmônicos, fáceis de serem guardadas no 'ouvido' dos fiéis: vamos dizer assim, 70\% dos nossos cânticos são extraídos do CC, e são cânticos mais simples, mais fáceis de serem assimilados (Elizeu). A melodia permanece e a letra muda, exigindo de quem canta uma maior atenção na letra que no material musical. Consiste aí, na visão de alguns músicos, principalmente em IBT, a eficácia da comunicação da música no momento do culto: ela é eficaz porque suporta bem os textos, a palavra que deve ser cantada.

Essa estratégia de preservar a música e mudar o texto, vinda dos tempos de Lutero, também é usada em IBP, vejamos como. Tomo como exemplo a primeira música cantada no culto de $02 / 10 / 2007$, Nada se compara. Olhando o esquema da forma temos:

INTRODUÇÃO - Y - X - Y - X' - Y - Y - INTERLÚDIO - Z - Z - Y* - Y* - Y* - FINAL 
A melodia aqui também é simples, a harmonia um pouco mais rebuscada, com muitas passagens, inversões e dissonâncias acrescentadas aos acordes. Devido ao acréscimo de outras partes, essa forma sai de um binário para cair no chamado rondó, outra forma cíclica, caracterizada pelo retorno em uma das partes. A parte em questão seria Y, o refrão. No intuito de fugir à previsibilidade, o compositor começa a música pelo refrão, coloca um interlúdio no qual modula a música de $\mathbf{C}$ (Dó maior) para $\mathbf{D}$ (ré maior), e acrescenta um final instrumental.

A repetição aqui também é vista como algo eficaz, no entanto, para essa liderança não é manter a música e mudar a letra que prende a atenção da congregação, e sim repetir música e letra sempre que possível, às vezes alterando o arranjo musical para que a letra seja fixada: em um determinado ponto alguns instrumentos param, voltam, há transposições. E como eles produzem música não apenas para o consumo interno da igreja, não deixam de estar atentos para as tendências de mercado:

Quando você começa a ouvir uma música, às vezes você tá vindo de um supermercado, vindo de algum lugar, até a sua mente entrar na música demora, num é uma coisa click... Às vezes a pessoa vai entender o refrão da música quando a música tá acabando. Se a música repetitiva não fosse boa comercialmente, ele não faria o sucesso que faz, e ela vende muito porque as pessoas gostam de fazer aquela oração repetidas vezes (Davi).

\section{- Performances}

Tal como a performance do culto deve obedecer à ordem impressa e determinada, assim também a performance musical deve obedecer às partituras impressas, em IBT. Mesmo quando os pianistas não tocam exatamente o arranjo coral proposto pelo CC, acrescentando arpejos e/ou oitavas, eles não fogem à estrutura dada: não modulam, não mudam a letra e nem acrescentam falas entre as estrofes. Buscam seguir o que a partitura propõe e prezam pela 'correção' performática, uma vez que estão conduzindo a congregação à adoração.

Apesar de parecer mais informal que em IBT, a performance de IBP também obedece à formas dadas. Não se muda radicalmente os arranjos, já conhecidos e gravados em CDs, no momento do culto. Os músicos tocam como eles tocaram no CD. O que a partitura representa para IBT, a gravação representa para IBP. Há, no entanto uma liberdade criada pelos momentos de espontâneo e pelas muitas falas colocadas por Davi na música, também conhecidas como ministrações.

- Timbres e estilos 
A instrumentação usada na performance de IBT é: piano acústico; piano elétrico na grande maioria das vezes com som de órgão -; às vezes um contrabaixo, fazendo a linha do baixo nos hinos, e voz. A voz é um instrumento muito privilegiado, uma vez que é aquele que porta o texto, e devido à formação musical da própria liderança, tem tendência a ser usada com uma impostação quase lírica. Piano e órgão são já instrumentos tradicionais no meio protestante, uma vez que, os arranjos dos hinos em estilo chorale, são mais facilmente interpretados nesses instrumentos. Preservar o som de órgão em um piano elétrico, com muitos outros recursos, é uma prática que aponta para a idéia de que a tradição vinda com os missionários norte-americanos dever ser mantida.

Já na performance de IBP, há, como as falas de seus músicos revelaram, uma variedade de estilos e timbres, muitos gerados dos vários recursos dos instrumentos elétricos, e mesmo de recursos eletrônicos como samplers e sintetizadores. Todos os instrumentos possuem seu valor e lugar nos arranjos, uma vez que cada música tem um ‘estilo' e um ritmo próprios da chamada 'música pop', ou como querem alguns do 'pop gospel'.

Segundo Beard, "o conceito de estilo refere-se à maneira ou modo de expressão, a forma com a qual os gestos musicais são articulados. Dessa forma, ele pode ser visto como relacionado ao conceito de identidade" (2005:170) [grifo do autor].

Identidade, talvez seja esse o termo.

[...] Depois veremos que a narrativa mítica foi uma tentativa de identificação do mundo. Desde a filosofia grega, encontramos reflexões sobre a identidade do indivíduo singular e do conceito universal, este homem e o homem, sobre a identidade e as diferenças, pois definir identidades é mostrar diferenças, Está implícito no conceito de identidade o conceito de diferença (Maia \& Miotello).

O conceito de diferença está embutido em identidade, mas apenas quando comparamos diferentes agentes entre si, porque, se colocamos o agente em confronto consigo mesmo, é possível que tenhamos a similaridade explícita. Isto digo porque, se confrontarmos as músicas feitas em IBT veremos a similaridade das formas - corais -, dos timbres - o piano e órgão - e do estilo de performance - a obediência a uma ordem prescrita. Se confrontarmos as músicas de IBP, ainda que aparentem uma variedade maior, elas serão formalmente parecidas - a repetição, as transposições -, os timbres clichês do mercado da música pop -, e a performance tendem à uma padronização. É um conjunto de iguais que só se tornam diferentes a frente de outro conjunto de iguais. 
- Familiarizando o novo porque o novo se tornou familiar: performando pseudoindividualizações

A padronização do 'novo' em familiar ocorre exatamente da necessidade de transformar o familiar em novo. Segundo Adorno (apud Middleton, 2002:46), isso pode ser observado nas categorias de análise aplicada aqui. $\mathrm{Na}$ forma, por exemplo, a repetição seria uma possibilidade de se rever uma experiência familiar, tal como uma não complicação harmônica, caracterizaria uma linguagem musical 'natural'. Ao que parece, IBT opera nesses termos. Já em IBP, ainda que repetição e 'naturalização' sejam percebidos, ocorrem também o que o autor chamou de "efeitos pseudoindividualizados", para chamar a atenção dos ouvintes, "confinados aos aspectos mais superficiais", uma vez que o "escopo para uma 'real' variedade é tão limitado que eles de fato se tornam rapidamente clichês, padrões deles mesmos" (2002:50).

Esses efeitos foram classificados em cinco categorias: 1) complicação harmônica através de substituição dos acordes primários; 2) complicação de efeitos rítmicos com o uso de síncopas; 3) coloridos e 'sujeiras' timbrísticas; 4) ‘blue notes' e 5) improvisações e paradas. Todas estas características podem ser encontradas nas músicas de IBP.

O pop gospel de IBP, na tentativa de variar, cria clichês que transitam entre a indústria cultural que produz a música de consumo gospel, ao passo que os clichês de IBT se criaram em tempos não tão recentes, mas se criaram e lá estão. $\mathrm{O}$ (in)formalismo do popular quer trazer elementos novos ao familiar. Estes elementos acabam se familiarizando e deixando de ser novos. O formalismo do que é imprenso (partituras, ordens de culto) quer manter o familiar simplesmente familiar. Ao que parece, as coisas esperam por elas mesmas em ambos os casos.

Superfícies diferentes, diferenças superficiais, que acabam implicando em processos bastante semelhantes. A existência de diferentes modos de vivência de música e culto sobre um mesmo nome de 'culto de igreja batista' parece não compreender essa diferença como proximidade. Então, as coisas se passam como se o que estivesse sendo atacado, nas idéias e práticas discursivas das vivências de cada uma, fosse a diferença; não as igrejas, as pessoas em si, mas o próprio processo de hibridação para se tornar diferente, ou a tentativa de não hibridação, para também se manter diferente. 


\section{Analisando performances: significados, delineações, inerências e experiências}

Em termos de significações dessas performances, eu talvez precisasse estabelecer primeiramente a quais tipos de significados estou me reportando, se afetivo, cognitivo, referencial, e assim por diante. No entanto, eu não creio nesse tipo de separação em se tratando de música e culto como cultura, e principalmente, de ambos enquanto vida; uma vez que a vida, ainda que possa ser analisada separadamente nesses compartimentos de afeto, cognição e referência, não é performada dessa forma. É sempre um todo com relação ao todo, e como diria Moraes refletindo Simmel, "a vida só se explica pela vida" (apud Ribeiro, 111:206). Performance é vida, e, por mais que em alguns momentos eu pareça tornar estáticos os significados aqui, por causa de análises localizadas, é fundamental saber que eles são dinâmicos, e que de fato, os significantes que geraram esses significados também o são. Além do que, são compreendidos e construídos individualmente, à revelia de toda forma ou estrutura social imposta. "Buscar o sentido é trazer à luz o que se assemelha", lembrando contudo que "a semelhança jamais permanece estável em si mesma" (Foucault, 1981:46); a semelhança é sempre a potencialidade da diferença.

\section{- Significações musicais - IBT}

Há uma fidelidade na performance interpretativa da tradição batista, das escolhas ideológicas em busca de um 'estar separado' do 'mundo', de se manter diferente frente as padronizações idiossincráticas de várias denominações, inclusive de outras linhagens batistas. Enfim, a música reflete e cria o ambiente de um campo de experiência e significação que parece ser o da celebração. Ali naquele espaço musical-religioso, as coisas se passam como se as pessoas se deleitassem no que fazem, compreendendo as inerências e delineações. Suas intenções são de perfeição performática (fidelidade a um texto) porque estão à frente, conduzindo uma comunidade através do contágio da experiência ela mesma, e a congregação parece responder também de forma positiva e celebrativa a toda essa experiência.

- Significações musicais - IBP

Um outro texto, mas que também pode ser lido sobre a ótica da celebração e da fidelidade. Inerências e delineações caminham de forma positiva para esse grupo que entende o culto e a música como vida. Pois como diria o jovem tecladista Salomão, "se eu não fosse músico eu seria um vegetal". Ainda que os padrões se pretendam 'nãopadrões', eles também celebram a estética e as normas voltadas para o marketing e a mídia ligada ao mundo gospel, evidenciando não só o consumo, mas também a 
expansão dos limites das relações do culto na igreja e fora dela. Tudo celebra e é fiel às idéias que ditam esse estilo. Tudo o que é artifício intencional, para que as coisas aconteçam, é vivido e as coisas acontecem. As manifestações dos dons espirituais almejados e presentes nos auges efervescentes de música e derramamento do Espírito, a interação emotiva entre os músicos e a congregação, parecem dar a completude de uma experiência que celebra o ser e o estar em um culto com músicas, e de músicas, para que se concretize as relações entre o homem, o sagrado e as necessidades sociais dessa interação.

\section{Mana- música}

Analisando tudo, ao que parece, é possível afirmar que toda música é diferente, e a mesma música se torna diferente ao ser interpretada e ouvida por pessoas diferentes. $\mathrm{O}$ que se mostrou similar aqui, no entanto, foram os processos musicais: a fidelização aos timbres, às partituras ou gravações, os aspectos formais da repetição. No entanto, se diferem em seus estilos, voltados ou não para o consumo, em suas performances espetaculares ou simples, em seus aspectos de função no culto ao simplesmente dar suporte ou ao se tornar a própria palavra, no verbo que se faz canto e no verbo que é canto. Se vistas de forma comparativa, poderíamos dizer que a experiência dessas duas igrejas, uma frente à outra, transitam no mundo das chamadas ambigüidades, no qual uma não compreende e/ou não aceita a forma como a outra se porta musicalmente. Uma produz música pra vender, outra somente para cultuar, porque uma entende o culto como algo além do culto, enquanto a outra, o vê como algo separado dos demais momentos da vida.

As idéias sobre música se mostraram atreladas não somente à história da formação musical de cada músico, mas também à história de cada igreja. Valores e compreensões de educação formal e informal, de música como profissão, de escolhas do 'ser santificado’ se separando das tendências do mercado e do sistema contemporâneo, ou de 'ser santificado' porque o mercado gospel é um mercado 'santo', tudo isso atua no resultado musical dos cultos. A forma como se crê o ser cristão, e mais, o ser cristão e batista, reflete (ou é gerado) pelas formas musicais assumidas, racionais formais, ou formais despojadas. Os músicos percebem tudo isso na medida em que compreendem a música como símbolo, ou seja, como mediadora, não só de homens e divino, mas também de homens e homens, em relações sociais que sanam as necessidades e os gostos musicais, para além da busca de Deus somente. A música revela e oculta 
padrões, valores e intenções, vindas de idéias não musicais, mas que, somente pelo viés da música conseguem transitar e se manter nesses meios. Porque música transita entre ser sentimento, arte, bem de consumo, objeto de manifestação, de defesa, de luta, de adoração...

Individualmente, todos se preparam de acordo com suas necessidades, sejam elas do domínio da técnica, sejam elas do preparo espiritual, e mesmo performances diferentes trazem pontos de similitude. Em ambos os casos há a mediação não da música, mas dos músicos: através da música eles levam as pessoas a adorar ao mesmo tempo em que é através da adoração - as próprias performances dos músicos - que as pessoas, como que por contágio, adoram. $\mathrm{O}$ deleite, a satisfação, a gratidão e reciprocidade de se fazer para Deus, embora o fato de que o que se faz é também para os homens, parece ser um ponto de significação, semelhantes em ambas as igrejas. Em IBT, o material musical, um suporte para a palavra, parece estar mais sujeito às delineações de um contexto de tradição que se quer, ainda que utopicamente, imutável, sólido. O material musical performado de forma séria e rígida, não admitindo idiossincrasias, sejam elas musicais ou não, complementa o espaço sério, 'neutro', introspectivo no qual é realizado o culto. Em IBP, delineações e inerências transitam entre si, porque a música suporta a palavra na mesma medida em que a palavra suporta a música, numa tradição voltada para um público e um mercado mais plásticos, que se diferem segundo os objetivos não só da publicidade, mas também da propaganda do material musical produzido. $\mathrm{O}$ espaço do culto, com todos seus artifícios de luz e efeitos visuais, é complementado pelos efeitos sonoros, bem como pelos efeitos retóricos do texto que acompanha a música. É no contato e no contágio que eclode a efervescência da profusão de tantos meios para uma efervescência sentimental comum.

Talvez toda essa interpretação seja tão ambígua quanto a própria experiência de ambigüidade de IBT e IBP frente a frente, carregada de incertezas. Mas como diria Fernando Pessoa, "há um Oasis no Incerto", um campo de virtualidades e potencialidades do que é, e do que pode ser, do existir e do sentido das coisas.

Depois de falar tanto em significação, admitir que as coisas não significam, mas existem, pode parecer um paradoxo, mas também pode ser visto como a estranheza que é o fato de querer tornar claro o que parece oculto, ou ocultar o que parece claro, pois este é o significado do existir. E, ao menos para mim, a música é um dos campos de potência mais frutífera nesse jogo de esconder e ocultar, mana dos cultos protestantes contemporâneos. Talvez mana de algo mais... 
A música não é simplesmente uma força, um ser; é uma ação, uma qualidade, um estado. Em outros termos, a palavra é ao mesmo tempo um substantivo, um adjetivo e um verbo. Diz-se que um objeto é musical para dizer que ele tem essa qualidade; neste caso, a palavra é uma espécie de adjetivo (aplicada a objetos que produzem som, e às pessoas que os produzem). Diz-se que um ser, espírito, homem, pássaro ou rio tem música - a musicalidade de fazer isto ou aquilo. Emprega-se a palavra música nas diversas formas das diversas conjugações e então ela pode significar "ter música", "dar música", "fazer música”, etc. Em resumo, essa palavra subentende uma massa de idéias que designaríamos pelas expressões: som humanamente organizado (Blacking, 1990); ser mágico que faz entrar em ressonância a ordem cósmica e que serva à magia, filosofia, ciência, medicina, educação e política (Hornbostel e Sachs apud Carvalho, 1999); meio de comunicação com o transcendente, os deuses, e os antepassados (Feld, 1982); meio de comunicação não verbal, ferramenta poderosa da auto-expressão, autoafirmação e autoconsciência humana com relação à cosmologia, bem como forte agente de coesão social (Béhague apud Lucas, 2002); arma defensiva e ofensiva na negociação de espaço (Frith, 2003); uma cultura, um contexto (Merriam [1975] apud Meyers, 1992). Uma massa de idéias cujo parentesco nem sempre entrevimos, uma vez que seus conceitos são dados separadamente e realiza essa confusão, que nos pareceu fundamental, entre o homem, o som e a cultura.

A idéia de música é uma dessas idéias turvas, de que nos cremos desembaraçados, e que, por isso, é-nos difícil definir. É obscura e vaga e, não obstante, tem um emprego estranhamente determinado. É abstrata e geral, mas muito concreta.

Parafraseei este texto de Mauss (1974: 138), quando da sua definição de mana. As proximidades entre mana e música, ao menos para mim são muito 'claras'. "O mana é exatamente o que dá valor às coisas e pessoas - valor mágico, valor religioso e até mesmo valor social" (Mauss, 1974:138). A música é um dos centros de existência desse trabalho. Esta música que tem seus aspectos mágicos, religiosos e, principalmente sociais. "Em segundo lugar, o mana é uma coisa, uma substância, uma essência manejável, mas também independente. [...] É passível de especialização: há mana para propiciar riqueza e há mana para matar" (1974: 139). E o que é a música senão uma coisa, uma substância e essência, que entre outras definições é vista como independente e autônoma, como obra e como ser, capaz de trabalhar afetos e gerar intenções? "Em terceiro lugar, o mana é uma força e especialmente a força dos seres espirituais, isto é, das almas dos ancestrais e dos espíritos da natureza" (1974: 139). Para quantos a música 
é exatamente essa força? Talvez para os indígenas brasileiros, ou da Guiné, para os diversos cristianismos, entre outras religiões; talvez mesmo para quem esteja lendo este texto.

“A música é portanto dada como algo não só misterioso, como também separado.[...] É também uma espécie de éter, imponderável, comunicável, que se expande por si mesmo. A música é, além disso, um ambiente, ou, mais exatamente funciona num ambiente que é música. É uma espécie de mundo interno e especial, onde tudo ocorre como se só a música estivesse ali em jogo. É a música do homem que age pela música do rito sobre a música dos espíritos o que abala outras músicas e assim por diante". ${ }^{17}$

\section{Referências}

AMARAL, Leila. Deus é pop: sobre a radicalidade do trânsito religioso na cultura de consumo. In SIEPIERSKI, Paulo D. e GIL, Benedito M. (org.). Religião no Brasil: enfoques dinâmicos e abordagens. São Paulo: Paulinas: 2003. p. 97-108.

ARAÚJO, Samuel. Louvor, música popular e mídia evangélica no Rio de Janeiro: utilização de músicas tradicionais em um determinado contexto de globalização. Revista Transcultural de Música, v.2, nov. 1996. Disponível em: $<$ http://www.sibetran.com/trans/trans2/araujo.htm>. Acesso em: 04 Nov. 2006.

BASTIDE, Roger. O sagrado selvagem. Cadernos de Campo. n. 8. São Paulo: USP, 1992.

BATAILlE, Georges. Teoria da Religião. Sérgio Goés de Paula e Viviane de Lamare (trad). São Paulo: Ática, 1993.

BEARD, David. Musicology: the key concepts. London and New York: Routledge, 2005.

BÍBLIA SAGRADA/HOLY BIBLE. São Paulo: Vida, 2003. (Nova Versão Internacional - NVI).

BLACKING, John. Music, culture and experience. Chicago and London: University of Chicago Press, 1995.

BLUM, Stephen. Analysis of musical style. In: MYERS, Helen. (ed.) Ethnomusicology: an introduction. London: Macmillan Press, 1992. p. 165-218.

BOLHMAN, Philip V. Music and culture: historiographies of disjuncture. In: CLAYTON, M; HERBERT, T; MIDDLETON, R. The cultural study of music: a critical introduction. New York and London: Routledge, 2003. p. 45-56.

CANTOR CRISTÃO. 6 ed. Rio de Janeiro: JUERP.

CARVALHO, Mário Vieira. Razão e sentimento na comunicação musical: estudos sobre a dialética do iluminismo. Lisboa: Relógio d'água, 1999.

CHASE, Gilbert. Do salmo ao Jazz - a música dos Estados Unidos. Samuel Penna Reis e Lino Vallandro (trad.). Rio de Janeiro: Globo, 1957.

COHN, Gabriel. As diferenças finas: de Simmel a Luhmann. Revista Brasileira de Ciências Sociais. Vol.13 n. 38. Out. São Paulo: 1998.

CRAPANZANO, Vincent. A cena: lançando sombra sobre o real. Mana. Rio de janeiro, vol.11, $\mathrm{n}^{\mathrm{o}} .2$, p.357-383, Out. 2005.

\footnotetext{
${ }^{17}$ Mais uma paráfrase de Mauss; 1974:141.
} 
CUNHA, Magali do Nascimento. "Vinho novo em odres velhos". Um olhar comunicacional sobre a explosão gospel no cenário evangélico no Brasil. Orientador: Luiz Roberto Alves. Tese (Doutorado em Comunicação). Escola de Comunicação e Artes da Universidade de São Paulo. São Paulo, 2004.

DOUGLAS, Mary. Pureza e Perigo. Sónia Pereira da Silva (trad.). Lisboa: Edições 70 [1966].

DURKHEIM, Émile. As formas elementares da vida religiosa: o sistema totêmico na Austrália. Paulo Neves (trad.). São Paulo: Martins Fontes, 1996.

ESPERANDIO, Mary Rute Gomes. A identidade Batista e o "espírito" da Modernidade. Protestantismo em Revista. Núcleo de Estudos e Pesquisa em Protestantismo - NEPP. Ano 04, n. 01, jan/abr. São Leopoldo: EST, 2005.

FATARELLI, Ueslei. "Cantai ao Senhor um cântico novo": influência da teologia da libertação no canto protestante brasileiro. (Dissertação de Mestrado). São Paulo: Universidade Presbiteriana Mackenzie, 2007.

FELD, Steven. Sound and sentiment: birds, weeping, poetics and song in Kaluli expression. Philadelphia: University of Pennsylvania Press, 1982.

FINNEGAN, Ruth. Music, experience, and the anthropology of emotion. In: CLAYTON, M; HERBERT, T; MIDDLETON, R. The cultural study of music: a critical introduction. New York and London: Routledge, 2003. p. 181-192.

FOUCAULT, Michel. As palavras e as coisas: uma arqueologia das Ciências Humanas. São Paulo: Martins Fontes, 1981.

. El ordem del discurso. Alberto Gaonzález Troyano (trad.). Buenos Aires: Torquets Editores, 1992.

FRITH, Simon. Music in everyday life. In: CLAYTON, M; HERBERT, T; MIDDLETON, R. The cultural study of music: a critical introduction. New York and London: Routledge, 2003. p. 92-101.

GREEN, Lucy. Music on deaf ears - musical meaning, ideology, education. Manchester and New York: St. Martin's Press, 1988.

HININGS, C. Robins; FOSTER, Bruce D. The organization structure of churches: a preliminary model. Sociology, 7. Sage Publications, 1973. p. 93

LEIRIS, Michel. Le sacré dans La vie quotidienne. In: HOLLIER, Denis. Le Collège de sociologie 91937-1939). Paris: Gallimard, 1979.

LONGO, Leila. Linguagem e psicanálise. Rio de Janeiro: Jorge Zahar, 2006.

LUCAS, Glaura. As sombras no espelho: percepção e interpretação em etnomusicologia. Trabalho apresentado na disciplina Etnomusicologia II, ministrada pela Prof. Dr. Elizabeth Travassos. UNIRIO, 2001. (Não publicado).

. Os sons do Rosário: o congado mineiro dos Arturos e Jatobá. Belo Horizonte: Editora UFMG, 2002.

MAIA, Rubens Dias; MIOTELLO, Valdemir. Identidade e linguagem. In: Linguagem e discurso. Disponível em: <http://www.ufscar.br/ ppgl/Rubens_Maia.pdf $>$. Acesso em 25 mai 2008.

MAUSS, Marcel. La prière. Les classiques des Sciences Sociales. Université du Québec à Chicoutimi. [1909]. Disponível em: $<$ http://www.uqac.uquebec.ca/zone30/Classiques_des_sciences_sociales/index.html $>$. Acesso em 01 nov 2008.

- Sociologia e Antropologia, com uma introdução à obra de Marcel Mauss, de Claude Lévi-Strauss. Lamberto Pucinello (trad.). São Paulo: EPU, 1974. vol. 1.

MENDONÇA, Antonio Gouvêa. O celeste porvir: a inserção do protestantismo no Brasil. São Paulo: IMS, 1995. 
MIDDLETON, Richard. Studing popular music. Milton Keynes: Open University Press, 2002.

MILLER, Mandi M.; STRONGMAN, Kennet T. The emotional effects of music on religious experience: a study of pentecostal-charismatic style of music and worship. Psychology of Music, 30. Sage Publications, 2002. p.8-27.

MORAES, Marcelo Jacques. O outro que se lê: "O Espelho" de Guimarães Rosa. Revista do Centro de Estudos Portugueses. Belo Horizonte, v.22, n. 30, 2002

MYERS, Helen. (ed.) Ethnomusicology: an introduction. London: Macmillan Press, 1992.

NETTL, Bruno. Improvisation. In: SADIE, S. (org). NEW GROVE Dictionary of music. Oxford Press, s.d. (CD-Rom).

PEREZ, 2000. Breves notas sobre a religiosidade brasileira. Brasil 500 anos. Belo Horizonte: Imprensa Oficial dos Poderes do Estado, 2000. Disponível em http://www.antropologia.com.br. Acesso em 12 mai 2008.

RIBEIRO, Jorge Cláudio. Georg Simmel, pensador da religiosidade moderna. Revista de Estudos da religião. n.2. 2006. p. 109-126. Disponível em: $<$ http://www.pucsp.br/rever/rv2_2006/p_ribeiro.pdf >. Acesso em 11 out. 2008.

SANTOS, Valdevino Rodrigues dos. Tempos de Exaltação: um estudo sobre a música e a glossolalia na Igreja do Evangelho Quadrangular. São Paulo: Annablume, 2005.

SIMMEL, Georg. As grandes cidades e a vida do espírito (1903). Mana. Vol.11 n.2. out. Rio de Janeiro:2005.

SLOBODA, John. Music and Worship: a psychologist's perspective. In: ASTLEY, J; TOMOTHY and SAVAGE, Mark. Creative Chords: studies in music, theology and Christian formation. Graceuruy, 2000. p. 110-125.

SOUZA, André Resende de. Igreja in concert: padres cantores, mídia e marketing. São Paulo: Fapesp, 2005.

SOUZA, Euridiana Silva. "E o verbo se fez canto": músicas, discursos e cultos evangélicos. (dissertação). Escola de Música da Universidade Federal de Minas Gerais. Belo Horizonte, 2009.

Entre nós e laços: a construção da identidade musical e social nas igrejas batistas de Divinópolis/MG. ENCONTRO INTERNACIONAL DA ABET, 3., 2006. São Paulo. [Anais eletrônicos...] São Paulo: ABET, 2006.

SOUZA, Zilmar Rodrigues de. A música evangélica e a indústria fonográfica no Brasil: anos 70 e 80. Anais do XIV Congresso da ANPPOM - Porto Alegre: 2003.

SUPICIC, Ivo. Music in society: a guide to Sociology of Music. New York: Pendragon Press, 1987. (Sociology of Music, n. 4).

THOMPSON, John B. Ideologia e cultura moderna: teoria social crítica dos meios de comunicação de massa. Petrópolis: Vozes, 1995.

YAMANE, David. Beyond beliefs: religion and the Sociology of Religion in America. Social Compass, 54 (1). Sage Publications, 2007. p. 33-48. 